\title{
An investigation on performance of onion price and market arrivals in major Indian markets
}

\author{
Nandini Saha1, Amit Kar \& P Kumar
}

Journal of Agriculture and Ecology

Volame-9 (June, 2020)

Journal of

ISSN: 2456-9410

Volume: 9

Journal of Agriculture and Ecology (2020) 9: 78-82 http://doi.org/10.53911/JAE.2020.9109 


\title{
An investigation on performance of onion price and market arrivals in major Indian markets
}

\author{
Nandini Saha ${ }^{1} \varnothing$, Amit $\operatorname{Kar}^{1} \&$ P Kumar ${ }^{1}$
}

${ }^{1}$ Division of Agricultural Economics, ICAR-Indian Agricultural Research Institute

$\square$ Corresponding author: Nandini Saha, nansnew@gmail.com

\section{Article Info}

Article history

Received: 20 August 2020

Accepted: 29 August 2020

Available online: 04 September 2020

Key Words: Onion, Trend, Seasonality, Variability, Instability.

\begin{abstract}
Onion is a significant and essential commodity used in all the Indian delicacies either in raw form or dehydrated form to add flavour and taste to cuisine. India is the $2^{\text {nd }}$ largest producer of onion next to china and it is also $2^{\text {nd }}$ highest yielded vegetable in India. Though it shares a considerable amount of area and production among all the vegetables along with high marketable surplus, it fails to approve steady price throughout the year. Instability in market arrival contributing to the price fluctuations is mainly caused by substantial dependence on meteorological conditions and perishable nature of the crop. Often this high price fluctuation and variation in price causes suffering to the farmers by affecting their income level. It impacts the consumers adversely and also causes inefficiency in the functioning of the market. Realising the importance of the situation, through this paper it has been investigated. The trends in market arrival were positive in three markets except Azadpur. Trend in nominal price is found positive and for real price it was found negative in all the markets. Seasonal index showed that the arrival in different markets remained on the higher side during the peak harvesting season of the particular region and it collides with the low seasonal price index. Variability index revealed the existence of high variability for both of price and arrivals of onion. However, because of presence of significant seasonality in prices there is scope for increasing the income of farmers by concentrating on marketing during lean periods.
\end{abstract}

Copyright (C2020 saha et al., This is an open access article published under the terms of the Creative Commons Attribution License, which permits unrestricted use, distribution, and reproduction in any medium, provided the original work is properly cited.

Preferred citation: Saha N, Kar A \& Kumar P. 2020. An investigation on performance of onion price and market arrivals in major Indian markets. Journal of Agriculture and Ecology, 9: 78-82; http://doi.org/10.53911/JAE.2020.9109.

\section{Introduction}

India is the second largest producer of vegetables only next to China. The vegetable sector is seen as very significant as it generates high incomes and employment, enhances nutrition, protects and maintains the environment (Kumar et al. 2005). Onion is an important and essential ingredient that is used in all Indian delicacies, either raw or dehydrated form to add flavor and taste to the cooking. India is World's second largest producer of Onion. Marketable surplus of onion is higher than other food crops but still it fails to keep the prices stable due to instability in market arrival. Perishable nature of the crop along with substantial dependence 
on meteorological conditions causes the instable market arrival leading to high price fluctuation. Higher price volatility in onion is a major concern for the farmers. The price instability is attributable in large part to changes in production and subsequent changes in market arrivals (Latwal et al. 2017) and also to disruptions in supply. The supply disruption along with short-term demand and supply inelasticity, leads to sharp price fluctuations. The situation for vegetable growers is further aggravated by the lack of market information (Singh et al. 2017). Often this high price fluctuation and variation in price causes suffering to the farmers by affecting their income level and also impacts the consumers adversely. Therefore, information regarding market arrival and price behaviour is very important for producer as well as consumers. With this background, the present paper is an overview of onion price and market arrivals behaviour in major Indian markets.

\section{Materials and Methods}

The present study is based on the secondary data. Daily price data of the major markets for the period 2009-2019 were collected from Directorate of Marketing and Inspection (www.agmarknet.gov.in) and weekly prices (Rupees per quintal) were calculated. Lasalgaon, Azadpur, Bangalore and Ahmedabad markets were selected as major markets. To achieve the objective of the study, these statistical techniques have been used:

\section{Linear trend}

The linear trends of market arrivals and prices of the vegetables were observed through linear trend equations in the form of li near regression as mentioned below.

$$
Y=\alpha+\beta t
$$

Where, $\mathrm{Y}=$ Market arrival/ Price of the crop, $\alpha=$ Intercept coefficient, $\beta=$ Regression coefficient, $\mathrm{t}=$ time variable

\section{Seasonal fluctuations}

Seasonal shifts in business activity that occurs on a regular basis each year is known as seasonal variation. The seasonality in market arrivals and price was studied using following multiplicative model

$$
Y_{t}=T_{t} * S_{t} * C_{t} * I_{t}
$$

Where,

Yt $=$ Wholesale prices/market arrivals of onion (Rs/q)

$\mathrm{T}_{\mathrm{t}}=$ Trend value at time $\mathrm{t}$,

$\mathrm{S}_{\mathrm{t}}=$ Seasonal fluctuation at time $\mathrm{t}$,

$\mathrm{C}_{\mathrm{t}}=$ Cyclic fluctuation at time $\mathrm{t}$,

$\mathrm{I}_{\mathrm{t}}=$ Irregular fluctuation at time $\mathrm{t}$.

It provides an index for evaluating the degree of the seasonal variation present in a time series.

\section{Cuddy-Della-Valle Index}

Cuddy Della Valle Index was used to estimate variability. The variability coefficient has been computed using the following formula

$$
C-D-V \text { Index }=C V \sqrt{ }\left(1-\bar{R}^{2}\right)
$$

Where $\mathrm{CV}=(\mathrm{SD} \div \mathrm{Mean}) * 100$ and $\bar{R}^{2}$ is

the adjusted estimated coefficient of

determination

\section{Results and Discussion}

Linear trend: The linear trend is used to compute the long-run movement of market arrivals and prices of onion during the period under study in the selected markets. The results are given in Table 1-3. The coefficient of arrivals is negative in Azadpur market which indicates that the arrivals of onion in 
this market were decreasing over time. However, Lasalgaon, Bangalore and Ahmedabad market recorded positive value of the coefficient which means onion arrivals has increased over the years during the study period. The coefficients indicate that per annum decrease in arrivals in Azadpur is 5.40 thousand quintals, and the per annum increase in arrivals in Lasalgaon is 8.42 thousand quintals, in Bangalore 42.08 thousand quintals and in Ahmedabad 7.95 thousand quintals. In case of nominal prices, the coefficients were found positive in all of the markets. The highest annual increase in onion prices was seen in Lasalgaon (Rs. 32.76/q). However, the linear trend of real prices was negative for all the markets.

Table 1. Trend in arrivals of onion

\begin{tabular}{lcc}
\hline Markets & Intercept & Coefficient \\
\hline Lasalgaon & 215687.3 & 8427.257 \\
Bangalore & 512086.1 & 42083.08 \\
Azadpur & 319929.8 & -5407.33 \\
Ahmedabad & 121271.7 & 7953.3 \\
\hline Table 2. Trend in nominal prices of onion \\
\hline Markets & Intercept & Coefficient \\
\hline Lasalgaon & 1017.11 & 32.76 \\
\hline Bangalore & 1000.50 & 31.76 \\
\hline Azadpur & 1136.39 & 21.19 \\
\hline
\end{tabular}

Table 3. Trend in real price of onion

\begin{tabular}{lcc}
\hline Markets & Intercept & Coefficient \\
\hline Lasalgaon & 8331.01 & -3.79 \\
Bangalore & 3175.36 & -1.23 \\
Azadpur & 17621.23 & -8.39 \\
Ahmedabad & 17422.66 & -8.30
\end{tabular}

Seasonal Indices: Seasonal shifts in business activity that occurs on a regular basis each year is known as seasonal variation. Seasonal variation in arrivals and price of onion is very much observable. The market arrivals of perishable crops are mainly determined by different human and organizational factors along with the climatic situation.

Indices of seasonal arrivals (Table 4) indicate that in Lasalgaon market the arrivals indices of onion were highest during the month of January and lowest in November. During January - February arrivals remain on the higher side as it is just after the peak harvesting season of kharif onion and it remains much lower just before the harvesting of onion. In Bangalore market the highest arrivals indices were in the month of October which is the prime harvesting time of kharif onion in Karnataka. In other two markets i.e. Ahmedabad and Azadpur market the arrival indices were found to be highest during April to June which is the harvesting season of Rabi onion in the northern India.

The seasonal indices of price in Lasalgaon market were found to be highest in November when the arrival indices were lowest. Due to lesser arrival of onion during that time the spike in onion price was higher. All the other 3 markets also exhibited similar pattern. 
Table 4. Seasonal indices of market arrivals and prices of onion

\begin{tabular}{lllllllll}
\hline & \multicolumn{7}{c}{ Markets } \\
\cline { 2 - 9 } & \multicolumn{2}{c}{ Lasalgaon } & \multicolumn{2}{c}{ Bangalore } & \multicolumn{2}{c}{ Azadpur } & \multicolumn{2}{c}{ Ahmedabad } \\
\hline Months & Arrivals & Price & Arrivals & Price & Arrivals & Price & Arrivals & Price \\
January & 181.4 & 98.3 & 90.4 & 101.4 & 87.0 & 103.8 & 102.3 & 101.9 \\
February & 146.3 & 80.0 & 78.7 & 90.5 & 89.9 & 91.9 & 101.1 & 88.6 \\
March & 58.8 & 66.3 & 89.1 & 72.3 & 95.9 & 81.4 & 104.5 & 75.2 \\
April & 72.5 & 58.8 & 74.3 & 62.7 & 98.6 & 72.9 & 118.3 & 64.3 \\
May & 136.2 & 62.4 & 76.3 & 66.5 & 107.5 & 64.1 & 109.2 & 58.2 \\
June & 114.5 & 81.9 & 73.7 & 82.6 & 115.0 & 72.5 & 105.2 & 75.6 \\
July & 110.3 & 100.1 & 70.2 & 102.0 & 101.4 & 91.0 & 91.8 & 94.9 \\
August & 84.0 & 139.2 & 78.8 & 122.6 & 91.5 & 122.7 & 81.0 & 127.5 \\
September & 56.7 & 114.5 & 120.2 & 121.0 & 97.2 & 119.3 & 97.4 & 113.8 \\
October & 59.3 & 136.0 & 192.4 & 122.7 & 92.8 & 139.1 & 97.2 & 132.4 \\
November & 37.7 & 151.3 & 136.3 & 138.4 & 107.9 & 133.3 & 103.0 & 140.4 \\
December & 138.0 & 112.1 & 117.6 & 117.8 & 113.9 & 108.4 & 89.1 & 127.2 \\
\hline
\end{tabular}

Variability: The variability of both arrivals and price of onion has been calculated using the C-D-V index. The result is presented in Table 5. Variability in prices is more pronounced than market arrival. Variability in market arrival is found highest in Bangalore market with an index of 49.72 per cent, while Ahmedabad market showed the lowest value with index of 28.62 per cent. Variability in prices was highest in Lasalgaon market with an index of 73.15 per cent. Bangalore market which accounted for the highest variability in market arrival exhibited the lowest variability in prices.
Table 5. Variability of market arrival and prices in all markets

\begin{tabular}{lcc}
\hline \multicolumn{3}{c}{ C-D-V Index (\%) } \\
\hline Markets & $\begin{array}{l}\text { Market } \\
\text { Arrival }\end{array}$ & Price \\
& 38.69 & 73.15 \\
\hline Lasalgaon & 49.72 & 63.24 \\
Bangalore & 63.74 \\
Azadpur & 29.58 & 70.14 \\
Ahmedabad & 28.62 & \\
\hline
\end{tabular}

\section{Conclusion}

Linear trend analysis showed that market arrivals have increased over the years across the markets except Azadpur. Nominal prices have positive trend however trend in real price was negative which depicts that in spite of increasing arrivals and nominal prices, the condition of the producers has actually 
worsened since there is negative trend of real prices over the years. Seasonality calculation revealed that arrival in different markets remained on the higher side during the peak harvesting season of the particular region and it collides with the low seasonal price index. Variability calculated with the help of CuddyDella-Valle Index revealed that variability in both arrival and prices were on the higher side but variability in price was more than that of arrival. This may be because onion price was subjected to high volatility. However, because of presence of significant seasonality in prices there is scope for increasing the income of producers by concentrating on marketing during lean periods. To do this, it is necessary to develop and strengthen market intelligence system, infrastructure along with better production techniques to achieve early or late harvest from the available varieties.

\section{References}

Ali J, Kachroo J, Bhat DJ \& Bhat A. 2018. Analysis of Prices and Arrivals of Apple Fruit in Narwal Market of
Jammu. Economic Affairs, 63(1): 107111.

Kumar V, Sharma HR \& Singh K. 2005. Behaviour of market arrivals and prices of selected vegetable crops: A study of four metropolitan markets. Agricultural Economics Research Review, 18 (2): 271-290.

Latwal M \& Kumar A. 2017. Market arrival and price behaviour of potato in Uttarakhand. International Journal of Development Research, 7(1): 1121911225.

Singh DK, Pynbianglang K \& Pandey N K. 2017. Market Arrival and Price behaviour of Potato in Agra district of Uttar Pradesh. Economic Affairs, 62(2): 341-345.

Thakare HP, Daundkar KS, Rathod SR \& Bondar US. 2017. Changes and trends in arrival and prices of agricultural commodities in APMC Kolhapur market. International Research Journal of Agricultural Economics and Statistics, 8(1): 26-30. 